\title{
PENGARUH PENGETAHUAN AKSEPTOR DENGAN PEMILIHAN KONTRASEPSI IMPLANT
}

\author{
Yunik Windarti \\ Fakultas Keperawatan dan Kebidanan \\ Universitas Nahdlatul Ulama Surabaya Jl. Smea 57 Surabaya \\ Email : yunikwinda@unusa.ac.id
}

\begin{abstract}
The influence of acceptor's knowledge with the selection of implant contraception. Implant is one of hormone contraceptive methode with high effectiveness. But, know fact that there were acceptors refused to use implant. The caused factor is the less off acceptors knowledge about implant. Therefore, this research was influence of acceptor's knowledge with the selection of implant contraception. The type of this research was analytic by non probability. The po samplingpulation involved 42 acceptors of hormonal contraceptive who attended on may at BPM Kusmawati Surabaya. 38 respondents were taken as the samples using accidental sampling technique. The independent variable was knowledge where as, the dependent one was the selection. Questionnaires was used to collect the data. Analyzed by using Mann-Whitney test with the significance level $\alpha=0,05$. The result of this research showed that most of respondents $(60,5 \%)$ had less knowledge and almost all respondents $(89,5 \%)$ did not use implant. Furthermore, the statistic test has obtarned $\mathrm{p}=0,039<\alpha=0,05$. So $\mathrm{H}_{0}$ was refused that there was influence of acceptor's knowledge with the selection of implant. The research concluded that the less of acceptors knowledge about implant. The used of this contraceptive is vower. Hence, the health workers should improve the counselling and implant extension to people.
\end{abstract}

Abstrak : Pengaruh pengetahuan akseptor dengan pemilihan kontrasepsi implant. Implant merupakan salah satu dari metode kontrasepsi hormonal yang memiliki efektivitas tinggi, namun kenyataannya masih banyak akseptor enggan menggunakan implant. Salah satu penyebab adalah kurangnya pengetahuan akseptor tentang implant. Penelitian ini bertujuan untuk mengetahui pengaruh pengetahuan akseptor dengan pemilihan kontrasepsi implant. Desain penelitian analitik non probability sampling. Populasinya semua akseptor hormonal yang melakukan kunjungan pada bulan Mei di BPM Kusmawati sebesar 42 orang. Sampel sebesar 38 responden diambil dengan tehnik "accidental sampling". Variabel independent pengetahuan dan variabel dependent pemilihan kontrasepsi implant. Pengumpulan data menggunakan kuesioner. Data dianalisa menggunakan uji Mann-Whitney dengan tingkat kemaknaan $\alpha=0,05$. Hasil penelitian menunjukkan sebagian besar responden $(60,5 \%)$ berpengetahuan kurang dan hampir seluruh responden $(89,5 \%)$ tidak menggunakan implant. Hasil uji statistik didapatkan $\rho=0,039<\alpha=0,05$, maka $\mathrm{H}_{0}$ ditolak artinya ada pengaruh pengetahuan akseptor dengan pemilihan kontrasepsi implant. Simpulan dari penelitian ini adalah semakin kurang pengetahuan akseptor tentang implant maka semakin rendah jumlah pemakaian kontrasepsi tersebut. Sehingga Bagi tenaga kesehatan diharapkan dapat meningkatkan konseling dan penyuluhan kepada masyarakat tentang implant.

Kata kunci : Pengetahuan akseptor, implant 


\section{PENDAHULUAN}

Keluarga kebercana adalah usaha untuk mengukur jumlah dan jarak anak yang diinginkan, salah satu cara agar rencana tersebut tercapai yaitu dengan pemakaian kontrasepsi. Adapun metode kontrasepsi ini dibagi menjadi tiga sesuai dengan efektivitasnya, yaitu metode kontrasepsi sederhana, metode kontrasepsi efektif, dan metode kontrasepsi mantap. Dari ketiga macam metode kontrasepsi diatas yang sangat dianjurkan dalam pemakaiannya adalah metode kontrasepsi efektif, yang dibagi menjadi dua yaitu non hormonal dan hormonal. Metode kontrasepsi hormonal terdiri dari tiga yaitu suntik, pil, dan implant. Namun yang memiliki banyak penggunanya adalah suntik dan pil. Sedangkan pada kenyataannya implant merupakan metode kontrasepsi hormonal yang memiliki efektivitas sangat tinggi serta memiliki angka kegagalan yang rendah. implant juga merupakan alat kontrasepsi yang sangat sesuai bagi pasangan usia subur yang ingin memakai kontrasepsi dalam jangka panjang untuk mengatur jarak kehamilan. Menurut BKKBN, program KB dengan penggunaan metode kontrasepsi jangka panjang masih kurang peminatnya termasuk implant (BKKBN, 2011).

Berdasarkan hasil studi pendahuluan

7 akseptor pil \& suntik dengan cara wawancara pada tanggal 8 Maret 2013 mengenai kontrasepsi implant didapatkan hanya 2 akseptor yang tahu tentang implant, Sementara 4 yang lain tidak tahu tentang implant, bahkan mereka mengaku enggan untuk memilih implant karena takut saat pemasangan serta adanya rumor bahwa implant dapat berpindah tempat, harga alat kontrasepsi implant yang mahal dibanding alat kontrasepsi suntik atau pil serta 1 responden mengatakan bahwa KB susuk dilarang oleh agama. Rendahnya jumlah peminat akseptor implant dapat disebabkan karena beberapa faktor seperti ketidaktahuan peserta tentang kelebihan implant dimana pengetahuan tentang alat kontrasepsi merupakan pertimbangan dalam menentukan metode kontrasepsi yang digunakan, faktor sumber ekonomi yang berkaitan erat dengan kemampuan untuk membeli alat kontrasepsi yang digunakan, sejumlah faktor budaya dapat mempengaruhi klien dalam memilih metode kontrasepsi, faktor tingkat pendidikan tidak saja mempengaruhi kerelaan menggunakan KB tetapi juga pemilihan suatu metode, di berbagai daerah kepercayaan religius juga dapat mempengaruhi klien dalam memilih metode (Handayani, 2010).

Rendahnya akseptor yang memilih alat kontrasepsi implant dapat mengakibatkan tingginya angka kegagalan pemakaian kontrasepsi. Sehingga dapat menimbulkan beberapa dampak, yaitu peningkatan angka kematian ibu dan anak, penurunan kesejahteraan keluarga, penurunan kapasitas sumber daya manusia, penurunan derajat kesehatan dan peningkatan masalah kesehatan reproduksi (Anggaraini, 2012).

Pemakaian alat kontrasepsi harus terus diupayakan meningkat. Berbagai macam cara bisa dilakukan diantaranya dengan penyuluhan pada sasaran atau WUS, program bakti sosial pemasangan alat kontrasepsi gratis, peran petugas kesehatan dioptimalkan, dan penyampaian informasi dari berbagai media cetak maupun elektronik tentang pentingnya alat kontrasepsi.

\section{METODE}

Desain penelitian yang digunakan adalah analitik dengan pendekatan yang digunakan non probability sampling, yaitu suatu penelitian dimana variabel independen (pengetahuan akseptor) dan dependen (Pemilihan kontrasepsi implant) diobservasi pada waktu yang sama. Populasi dalam penelitian adalah semua akseptor hormonal yang melakukan kunjungan pada bulan Mei di BPM Kusmawati Surabaya sebesar 42 
orang kemudian diambel sampel sebesar 38 orang. Tehnik sampling dilakukan secara non probability sampling dengan teknik accidental sampling. Variabel independen dalam penelitian ini pengetahuan akseptor, dan variabel dependent pemilihan kontrasepsi implant. Instrumen yang digunakan berupa kuesioner.

Data dianalisis dengan menggunakan uji statistik Mann-whtney dengan menggunakan SPSS for Windows dan tingkat signifikasi $\alpha=0,05$. Ho ditolak bila $\mathrm{p}<\alpha$ yang berarti ada pengaruh pengetahuan akseptor dengan pemilihan kontrasepsi implant.

\section{HASIL DAN PEMBAHASAN}

Karakteristik responden berdasarkan pengetahuan

Tabel 1 Distribusi frekuensi responden berdasarkan pengetahuan di BPM Kusmawati Surabaya pada bulan Mei 2013

\begin{tabular}{|c|c|c|}
\hline Pergetahuan & Frekuensi (n) & Persentase (\%) \\
\hline Bails & 3 & 7,9 \\
\hline Cukup & 12 & 31,6 \\
\hline Kurang & 23 & 60,5 \\
\hline Jumlah & 38 & 100 \\
\hline
\end{tabular}

Pada tabel 1 menunjukkan bahwa dari 38 responden sebagian besar $(60,5 \%)$ memiliki pengetahuan kurang.

Karakteristik responden berdasarkan pemilihan kontrasepsi implant

Tabel 2 Distribusi frekuensi responden berdasarkan pemilihan kontrasepsi implant di BPM Kusmawati Surabaya pada bulan Mei 2013

\begin{tabular}{|c|c|c|}
\hline Pemilihan implant & Fresuensi (in) & Pexentase (\%) \\
\hline$Y_{a}$ & 4 & 10,5 \\
\hline Ticádk & 34 & 89,5 \\
\hline Jumiah & 38 & 100 \\
\hline
\end{tabular}

Pada tabel 2 menunjukkan bahwa dari 38 responden hampir seluruhnya $(89,5 \%)$ tidak memilih kontrasepsi implant.

Tabel 3. Pengaruh pengetahuan akseptor dengan pemilihan kontrasepsi implant di BPM Kusmawati pada bulan Mei 2013.

\begin{tabular}{|c|c|c|c|c|c|c|c|}
\hline \multirow[t]{2}{*}{ Pencetahuar } & \multicolumn{6}{|c|}{ Pemilihan kontraseps implant } & \multirow[t]{2}{*}{ Jumlah } \\
\hline & & \begin{tabular}{l|l}
$Y_{2}$ \\
\end{tabular} & & & Tidak & & \\
\hline & n & & $\%$ & ! & & $\%$ & {$[(\%)$} \\
\hline Baik & 2 & & 66,7 & 1 & & 33,3 & $3(100)$ \\
\hline Cukup & 1 & & 8.3 & 11 & & 91,7 & $12(100)$ \\
\hline Kurarg & 1 & & 4,3 & 22 & & 95,7 & $23(100)$ \\
\hline Jumlah & 4 & & 10,5 & 34 & & 89,5 & $38(100)$ \\
\hline
\end{tabular}

Berdasar tabel 3 menunjukkan menunjukkan bahwa dari 3 responden yang memiliki pengetahuan baik sebagian besar $(66,7 \%)$ memilih implant, dari 12 responden yang memiliki pengetahuan cukup hampir seluruhnya $(91,7 \%)$ tidak memilih implant sedangkan dari 23 responden yang memiliki pengetahuan kurang hampir seluruhnya $(95,7 \%)$ tidak memilih implant.

Berdasarkan hasil uji Mann Whitney didapatkan nilai $\rho=0,039$ dan $\alpha=0,05$. Karena $\rho(0,039)<\alpha(0.05)$, maka hipotesis nihil $\left(\mathrm{H}_{0}\right)$ ditolak yang artinya ada pengaruh pengetahuan akseptor dengan pemilihan kontrasepsi implant, dimana akseptor yang memilih kontrasepsi implant masih rendah jumlahnya.

\section{PEMBAHASAN}

Pengetahuan

Berdasarkan tabel 1 didapatkan hasil bahwa dari 38 responden sebagian besar $(60,5 \%)$ memiliki pengetahuan kurang tentang implant. Kurangnya pengetahuan akseptor tentang implant dapat disebabkan karena beberapa hal, pertama kurangnya konseling yang dilakukan tenaga kesehatan pada calon akseptor baru tentang kontrasepsi implant. Dari 4 tenaga kesehatan yang melakukan konseling $\mathrm{KB}$, hanya 1 yang 
memberikan konseling secara lengkap tentang alat kontrasepsi. Tenaga kesehatan cenderung hanya memberikan konseling tentang kontrasepsi yang akan dipilih oleh akseptor baru tersebut. Kedua minimnya sumber informasi tentang implant karena informasi mengenai implant merupakan salah satu sumber informasi yang susah didapatkan sehingga akseptor cenderung mencari informasi dari lingkungan sekitar yang menghasilkan persepsi salah tentang implant. Hal ini sesuai dengan teori (Hartanto, 2010). Seseorang yang kurang memanfaatkan pelayanan kesehatan dapat disebabkan karena kurangnya pengetahuan tentang kesehatan termasuk metode kontrasepsi.

Dari rekapitulasi kuesioner, diketahui masih banyak akseptor di BPM Kusmawati belum mengetahui tentang efektivitas implant, hal ini disebabkan karena beberapa akseptor percaya bahwa bahwa kontrasepsi yang dipilih yaitu pil dan suntik sangatlah efektif dibandingkan dengan kontrasepsi implant. Akseptor juga tidak mengetahui tentang pengembalian kesuburan, lebih mempercayai bahwa apabila menggunakan implant waktu pengembalian kesuburan implant sangat lama. Pengetahuan seseorang dipengaruhi beberapa faktor diantaranya umur, pendidikan, dan pekerjaan (Mubarak, 2007).

Periode umur 20-40 tahun tergolong dalam kelompok yang sudah matang dan dewasa. Pada umur 20-40 tahun seharusnya seseorang akan lebih mudah dalam memperoleh pengetahuan, namun pada kenyataannya tidak semua orang pada periode ini akan memperoleh pengetahuan yang baik termasuk pengetahuan mengenai kontrasepsi implant. Hal ini tidak sesuai dengan teori yang menyatakan bahwa pada umur 20-40 tahun kemampuan untuk berfikir seseorang semakin matang dan dewasa, terjadi akibat pematangan fungsi organ pada aspek psikologis, dan mental (Mubarak, 2007). Berarti terdapat faktor lain yang lebih mempengaruhi pengetahuan akseptor tentang implant selain faktor umur.

Tingkat pendidikan akseptor setengahnya (50\%) adalah Sekolah Dasar. Tingkat pendidikan mempengaruhi pengetahuan seseorang termasuk pengetahuan tentang kesehatan. Hal ini menyebabkan seseorang tidak dapat berfikir secara rasional sehingga lebih mudah percaya dengan pendapat lingkungan sekitar tentang kontrasepsi implant tanpa mencoba untuk mendapatkan informasi yang lebih terpercaya. Hal tersebut sesuai dengan teori bahwa tingkat pendidikan yang rendah akan menghambat perkembangan sikap seseorang terhadap nilai-nilai yang baru dikenalkan (Notoatmodjo, 2006).

Pada penelitian ini, sebagian besar $(52,6$ $\%)$ adalah ibu bekerja. Seorang ibu yang bekerja seharusnya memiliki lebih banyak pengetahuan dibandingkan dengan seorang ibu yang tidak bekerja, namun pada kenyataannya pengetahuan ibu yang bekerja dan tidak bekerja sama-sama kurang terutama pengetahuan tentang implant. Hal ini tidak sesuai dengan teori yang mengatakan bahwa pekerjaan dapat menjadikan seseorang memperoleh pengalaman dan pengetahuan baik secara langsung maupun secara tidak langsung (Notoatmodjo, 2006).

\section{Pemiihan Kontrasepsi Implant}

Berdasarkan tabel 2 menunjukkan bahwa dari 38 responden hampir seluruhnya $(89,5 \%)$ tidak memilih implant. Hal tersebut menunjukkan bahwa responden yang menggunakan implant masih rendah. Rendahnya pemakaian implant disebabkan beberapa faktor, yaitu usia, sikap, pendidikan dan pengetahuan. Serta sebagian masyarakat disana mempercayai mitos bahwa implant dapat berpindah tempat, sehingga mereka lebih memilih kontrasepsi lain karena mengikuti riwayat kontrasepsi terdahulu.

Dari rekapitulasi kuesioner, 14 akseptor yang menggunakan pil 10 diantaranya 
memiliki alasan bahwa menggunakan pil karena murah, 20 akseptor yang menggunakan suntik 11 diantaranya memiliki alasan bahwa menggunakan suntik karena praktis. Pengetahuan antara satu wanita dengan wanita lain bervariasi, pengetahuan dapat mempengaruhi dalam pemakaian kontrasepsi. Berdasarkan hasil penelitian menunjukkan bahwa dari 23 responden yang memiliki pengetahuan kurang hampir seluruhnya $(95,7 \%)$ tidak memilih implant.

Tingkat pengetahuan kurang pada seorang wanita mempengaruhi pola pikir atau pemahaman seseorang tentang implant. Sehingga pada seorang wanita dengan tingkat pengetahuan kurang memiliki kecenderungan untuk tidak menggunakan implant karena adanya persepsi yang salah tentang implant mulai dari rasa sakit saat pemasangan dan pasca pemasangan hingga efektivitas implant dan waktu pengembalian kesuburan implant. Hal ini sesuai dengan teori semakin baik pengetahuan seseorang maka kesadaran untuk memperoleh pelayanan kesehatan termasuk kontrasepsi yang memiliki efektivitas tinggi akan semakin meningkat (Glasier dan Gebbie, 2005).

Dari 4 akseptor yang menggunakan implant 2 diantaranya memiliki alasan menggunakan implant karena permintaan suami dan 2 yang lain memiliki alasan menggunakan implant karena praktis. Jadi dapat disimpulkan bahwa faktor pengetahuan bukanlah salah satu faktor yang menyebabkan seorang akseptor enggan menggunakan implant.

Seorang wanita multipara cenderung lebih memilih menggunakan pil dan suntik dibandingkan menggunakan implant, padahal implant memilki efektivitas lebih tinggi dibanding dengan suntik dan pil. Serta implant dapat digunakan dalam jangka panjang untuk mengatur jarak kehamilan. Hal ini tidak sesuai dengan teori yang menyatakan bahwa semakin tinggi paritas yaitu ibu yang memiliki anak lebih dari empat seorang wanita maka beberapa metode efektif jangka panjang (AKDR, implan, MOW, MOP) dapat digunakan untuk menghentikan terjadinya kehamilan di masa mendatang (Glasier dan Gebbie, 2005).

Pengaruh pengetahuan akseptor dengan pemilihan kontrasepsi implant

Setelah dilakukan tabulasi silang antara kedua variabel dari penghitungan uji statistik mann-Whitney didapatkan nilai $\mathrm{p}=$ 0,039 dan $\alpha=0,05$. Karena $\mathrm{p}(0,039)<\alpha$ (0.05), maka hipotesis nihil $\left(\mathrm{H}_{0}\right)$ ditolak yang artinya ada pengaruh pengetahuan akseptor dengan pemilihan kontrasepsi implant. Hal ini ditunjukkan pada tabel 3 menunjukkan bahwa dari 3 responden yang memiliki pengetahuan baik sebagian besar $(66,7 \%)$ menggunakan implant, dari 12 responden yang memiliki pengetahuan cukup sebagian besar $(91,7 \%)$ tidak menggunakan implant sedangkan dari 23 responden yang memiliki pengetahuan kurang hampir seluruhnya $(95,7 \%)$ tidak menggunakan implant. Pengetahuan akseptor yang kurang tentang implant dapat mengakibatkan kesalahan persepsi serta sikap akseptor terhadap kontrasepsi implant tersebut, sehingga menyebabkan rendahnya jumlah akseptor implant.

Pengetahuan antara satu wanita dengan wanita lain bervariasi, pengetahuan dapat mempengaruhi dalam pemakaian kontrasepsi. Berdasarkan hasil penelitian menunjukkan bahwa dari 23 responden yang memiliki pengetahuan kurang hampir seluruhnya (95,7\%) tidak memilih implant. Tingkat pengetahuan kurang pada seorang wanita mempengaruhi pola pikir atau pemahaman seseorang tentang implant. Sehingga pada seorang wanita dengan tingkat pengetahuan kurang memiliki kecenderungan untuk tidak menggunakan implant karena adanya persepsi yang salah tentang implant mulai dari rasa sakit saat pemasangan dan pasca pemasangan 
hingga efektivitas implant dan waktu pengembalian kesuburan implant. Hal ini sesuai dengan teori semakin baik pengetahuan seseorang maka kesadaran untuk memperoleh pelayanan kesehatan termasuk kontrasepsi yang memiliki efektivitas tinggi akan semakin meningkat (Glasier dan Gebbie, 2005).

Selain itu dari 3 responden yang memiliki pengetahuan baik sebagian besar (66.7 \%) menggunakan implant. Karena pengetahuan yang baik tentang implant akan mempengaruhi seorang wanita untuk menggunakan kontrasepsi implant. Hal ini dikarenakan responden mengetahui bahwa kontrasepsi implant memiliki efektivitas tinggi, dapat digunakan selama 3 tahun serta tidak memerlukan kunjungan rutin ke tenaga kesehatan. Hal ini sesuai dengan teori dari BKKBN (2011), yang mengatakan bahwa pengetahuan yang baik tentang $\mathrm{KB}$ akan mempengaruhi pemakaian kontrasepsi yang tepat dan dengan suatu perilaku atau didasari oleh pengetahuan serta mengerti manfaat dari kontrasepsi dan membuat ibu dengan sendirinya memutuskan kontrasepsi yang cocok untuk digunakan.

Rendahnya jumlah masyarakat yang menggunakan Implant sebagai alat kontrasepsi dapat disebabkan karena keterbatasan pengetahuan seseorang tentang implant. Untuk mengatasi hal tersebut petugas kesehatan dapat melakukan penyuluhan dan membagikan leaflet kepada akseptor tentang implant. Hal ini diperkuat oleh pernyataan menurut Notoatmodjo “ apabila penerimaan perilaku baru atau adopsi perilaku melalui proses dan didasari oleh pengetahuan, kesadaran, dan sikap yang positif, maka perilaku tersebut akan bersifat langgeng (long lasting). Sebaliknya apabila perilaku itu tidak didasari oleh pengetahuan dan kesadaran maka tidak akan berlangsung lama'" (Notoadmodjo, 2005).

\section{SIMPULAN}

1. Akseptor di BPM Kusmawati sebagian besar memiliki pengetahuan kurang tentang implant.

2. Akseptor di BPM Kusmawati hampir seluruhnya tidak memilih kontrasepsi implant.

3. Ada pengaruh pengetahuan akseptor dengan pemilihan kontrasepsi implant.

\section{SARAN}

1. Bagi tempat pelayanan

Tenaga kesehatan meningkatkan konseling tentang semua jenis alat kontrasepsi sehingga dapat menurunkan angka kegagalan kontrasepsi serta dapat meningkatkan pengetahuan akseptor tentang kontrasepsi.

2. Bagi peneliti selanjutnya

Menjadi referensi dalam mengembangkan hasil penelitian selanjutnya tentang faktor-faktor lain yang mempengaruhi pemakaian implant.

3. Bagi akseptor

Akseptor yang memiliki pengetahuan kurang tentang kontrasepsi, lebih aktif untuk mengikuti kegiatan-kegiatan penyuluhan yang diadakan oleh tenaga kesehatan maupun mencari informasi baik melalui media cetak maupun elektronik.

\section{DAFTAR RUJUKAN}

Anggaraini, Yetti dan Martini. 2012. Pelayanan Keluarga Berencana. Jakarta: Rohima Press

BKKBN. 2011. Evaluasi Hasil Pencapaian Program KB Nasional Bulan November 2011 Provinsi Jawa Timur. Surabaya: BKKBN 
Glasier, Anna dan Ailsa, Gebbie. 2005.

Keluarga Berencana dan Kesehatan

Reproduksi. Jakarta: EGC

Handayani, Sri. 2010. Buku Ajar Pelayanan

Keluarga Berencana. Jakarta:

Pustaka Sinar Harapan

Hartanto, Hanafi. 2010. Keluarga Berencana dan Kontrasepsi. Jakarta: Pustaka Sinar Harapan

Mubarak, Wahid Iqbal. 2007. Promosi Kesehatan. Jogjakarta: Graha Ilmu

Notoadmodjo, Soekidjo. 2005. Promosi Kesehatan Teori dan Aplikasi. Jakarta: PT.Bhineka Cipta

Notoadmodjo, Soekidjo. 2006. Pendidikan dan Perilaku Kesehatan. Jakarta: PT.Bhineka Cipta

Notoadmodjo, Soekidjo. 2010. Metodologi Penelitian Kesehatan. Jakarta: PT.Bhineka Cipta 